\title{
PETERSEN 型資源量推定法の一吟味
}

\author{
能勢 幸焳 \\ (1961 年 6 月 12 日受理)
}

\section{AN ANALYSIS OF THE PETERSEN-TYPE FISH POPULATION ESTIMATE.}

\author{
Yukio NosE*
}

\begin{abstract}
Assuming that the diminution of tags which involves the extra natural mortality of the tagged fish and the loss of tags, occurs at a constant rate throughout the period of experimentation, the extent of overestimation in the PETERSEN-type estimate, caused by the above factors was analysed. The calculation showed that the bias of estimate increases as time passes and tends to approach the maximum limit which is determined by the ratio of the tag diminution coefficient to the total mortality coefficient (Eqns. 4, Table 1 and Fig. 1).

In order to eliminate this bias, a method based on the series of sample tag ratios obtained for regular intervals after liberation, was deduced (Eqns. 7 and 14).

The validity of this method was ascertained by the bead drawing experiment and comparing the results obtained by this method with those of simple PETERSEN method and the BEVERTON method, the advantages and disadvantages were discussed. It was also shown that the size of natural mortality coefficient may roughly be estimated by using the Author's method and the BEvERTON method together (Table 4).
\end{abstract}

PETERSEN 型の䅇識放流で放流時の筫源㔫数を推定するさい，充たされていなければならないいくつかの

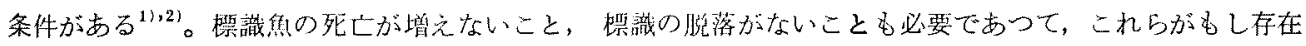
するなら推定值は過大になる。

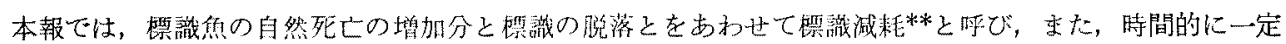

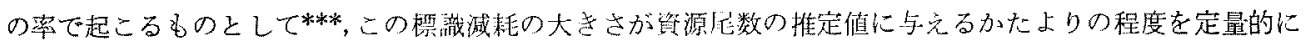

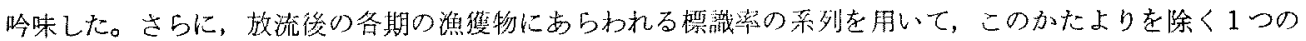

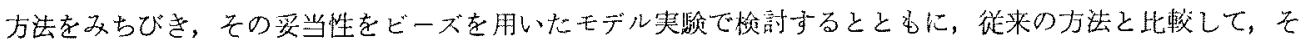
の得失を論じた。

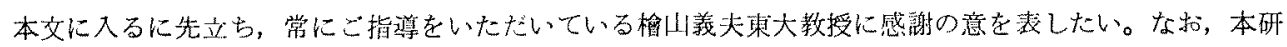

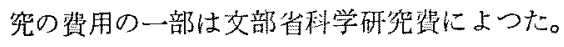

標識減耗のあるときの推定値のかたよりの大きさ

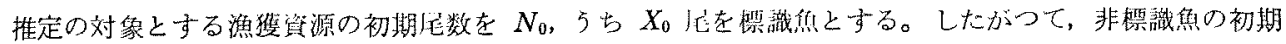

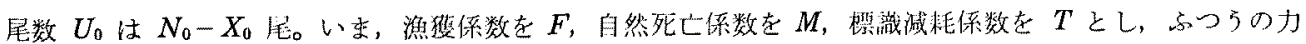

* 東京大学農学部水産学科 (Fish. Inst., Fac. of Agr., Univ. of Tokyo).

** CLARK と JANSSEN (1945) は Tagging mortality と表現している゙!。ただ，その内容は故流直後

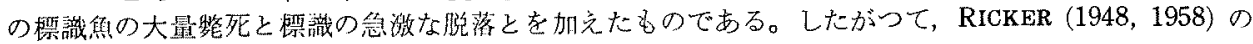
A 型の誤差原因にあたる。

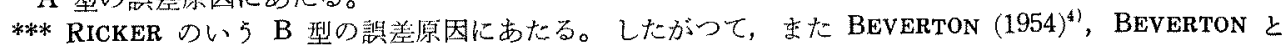
HoLT $(1957)^{5)}$ の第 II 型の誤羑原因と同義である。 
学的モデルを用いて，第 $r$ 期までの非標識魯の総㴔獲尾数 $C_{\sigma_{r}}$ および標識魚の再捕尾数 $C_{X_{r}}$ を求めると，

$$
\begin{aligned}
C_{U r} & =\frac{F U_{0}}{F+M}\left(1-e^{-(F+M) r}\right) \\
C_{X r} & =\frac{F X_{0}}{F+M+T}\left(1-e^{-(F+M+T) r}\right)
\end{aligned}
$$

を得る。ただし，放流後の各小期間（日，週，旬）の単位を 1 とし，F，M，Tをそれそれこの単位にもと ふいてはからたものとする。

したがつて，第 $r$ 期までの総漁獲尾数 $\left(C_{U r}+C_{X_{r}}\right)$ と再捕岑数 $C_{X_{r}}$ とを用いて，PETERSEN 流の推定を 行なうと, $\hat{N}_{0}$ の推定值 $N_{(r)}$ は,

$$
\hat{N}_{(r)}=X_{0}+U_{0} \frac{(F+M+T)\left(1-e^{-(F+M) r}\right)}{(F+M)\left(1-e^{-(F+M+T) r}\right)}
$$

となる。

(3) 式で, $T=0$ ，すなわら標譏隇耗が全くないときは常に $\hat{N}_{(r)}=X_{0}+U_{0}=N_{0}$ となつて推定值にはかた よりを生じない。しかし， $T>0$ のときは，rの增加にともなつて $\hat{N}_{(r)}$ は增大し， $X_{0}+U_{0}(F+M+T) /$ $(F+M)$ に近らく。この場合， $F$ と $M$ はとの和，すなわち全減少倸数 $Z$ として倕らくので， $Z$ が同しな ら $F$ そ $M$ の割合がどう変つても過大推定の程度柱等しい。ただし， $F$ の割合が大きい汪ど雨捕尾数が增 光, $\hat{N}_{(r)}$ の信頼限界はせまくなる。

いま，推定値のかたよりの大きさを， $\hat{N}_{(r)}$ と $N_{0}$ の此として表わし，これを $\gamma(r)$ とすると，

$$
\gamma(r)=P\left\{1-\frac{(F+M+T)\left(1-e^{-(F+M) r}\right)}{(F+M)\left(1-e^{-(F+M+T) r}\right)}\right\}+\frac{(F+M+T)\left(1-e^{-(F+M) r}\right)}{(F+M)\left(1-e^{-(F+M+T) r}\right)}
$$

\begin{tabular}{|c|c|c|c|c|c|c|c|c|c|c|}
\hline \multirow{9}{*}{$T=0.01$} & & 0.01 & 0.02 & 0.05 & 0.10 & $Z$ & 0.01 & 0.02 & 0.05 & 0.10 \\
\hline & 1 & 1.01 & 1.01 & 1.01 & 1.01 & \multirow{8}{*}{$T=0.05$} & 1.03 & 1.03 & 1.03 & 1.03 \\
\hline & 2 & 1.01 & 1.01 & 1.01 & 1.01 & & 1.05 & 1.05 & 1.05 & 1.05 \\
\hline & 3 & 1.02 & 1.02 & 1.01 & 1.01 & & 1.08 & 1.08 & 1.08 & 1.07 \\
\hline & 4 & 1.02 & 1.02 & 1.02 & 1.02 & & 1.10 & 1.10 & 1.10 & 1.10 \\
\hline & 5 & 1.03 & 1.03 & 1.02 & 1.02 & & 1.13 & 1.13 & 1.12 & 1.12 \\
\hline & 10 & 1.05 & 1.05 & 1.05 & 1.04 & & 1.27 & 1.26 & 1.24 & 1.22 \\
\hline & 20 & 1.10 & 1.10 & 1.09 & 1.07 & & 1.56 & 1.51 & 1.46 & 1.36 \\
\hline & 50 & 1.25 & 1.22 & 1.16 & 1.10 & & 2.48 & 2.28 & 1.85 & 1.50 \\
\hline \multirow{8}{*}{$T=0.02$} & 1 & 1.01 & 1.01 & 1.01 & 1.01 & \multirow{8}{*}{$T=0.10$} & 1.06 & 1.05 & 1.05 & 1.05 \\
\hline & 2 & 1.02 & 1.02 & 1.02 & 1.02 & & 1.10 & 1.10 & 1.10 & 1.10 \\
\hline & 3 & 1.03 & 1.03 & 1.03 & 1.03 & & 1.16 & 1.16 & 1.15 & 1.15 \\
\hline & 4 & 1.04 & 1.04 & 1.04 & 1.04 & & 1.21 & 1.21 & 1.20 & 1.20 \\
\hline & 5 & 1.05 & 1.05 & 1.05 & 1.05 & & 1.27 & 1.27 & 1.26 & 1.24 \\
\hline & 10 & 1.10 & 1.10 & 1.09 & 1.09 & & 1.57 & 1.56 & 1.52 & 1.46 \\
\hline & 20 & 1.20 & 1.20 & 1.18 & 1.14 & & 2.24 & 2.18 & 1.99 & 1.76 \\
\hline & 50 & 1.52 & 1.46 & 1.32 & 1.20 & & 4.36 & 3.80 & 2.76 & 1.99 \\
\hline
\end{tabular}

Table 1. The extent of overestimation in the PETERSEN-type estimate, caused by the diminution of tags. The bias is represented as the ratio of the estimate to the true size of initial fish population.

$Z$ : Total mortality coefficient. $\quad T$ : Tag diminution coefficient.

$r$ : The time after liberation, when the estimation is done. 

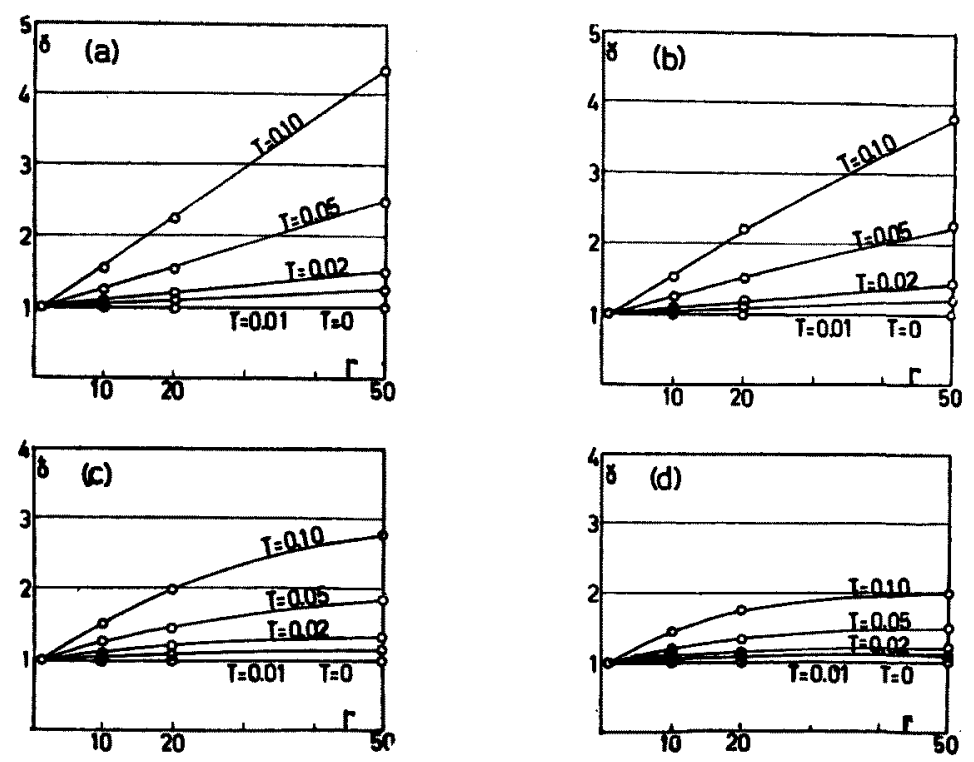

Fig. 1. $\gamma$, the ratio of the PETERSEN estimate to the true size of initial fish population. (Same data as in Table 1)

(a) $Z=0.01$, (b) $Z=0.02$, (c) $Z=0.05$, (d) $Z=0.10$

を得る。ただし，P=X $X_{0} / N_{0}$ (初めの標識率)である。

(4) 式の第1項のカッコ内は常に負であるから，P が大きいときほど，かたより率 $\gamma_{(r)}$ は相対的に減少

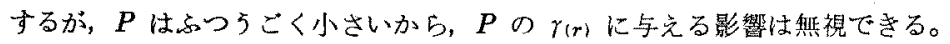

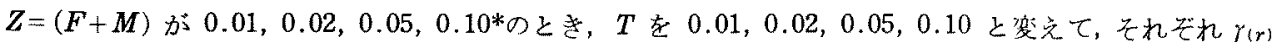
を計算した結果が Table 1 でりりこれを図示したのが Fig. 1 である。ここでは，P=0 として部算した。

Table 1, Fig. 1 から明らかなよ5に，推定值 $\hat{N}_{(r)}$ のかたより率 $\gamma(r)$ は $Z$ と $T$ の相対的な大きさ牱 よび $r$ できる。すなわち， $T$ が大きいときほど $\gamma(r)$ は相刘的に大きいが，同じ大きさの $T$ に対しては $Z$ が大きいときほど $\gamma(r)$ は小さくなる。ただし， $Z$ が大きいとき汪ど，その $Z$ と Tできまる $\gamma_{(r)}$ の最 大值 $(Z+T) / Z$ に急速に近づくこがかかる。

$F, M$ が放流後の各期で変化するときの $\gamma(r)$ は，場合によつてまちまちであるが，このときる $\gamma(r)$ は常 に1より大きく，rの增加とともなつて $(F+M)_{r}$ の最大と最小がそれでれ継続した場合に得られる2つ の曲線の間に落ちることは疑いない。

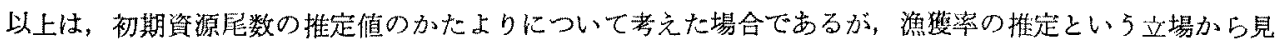
ると逆に同程度に過小推定に楩ることを注意して抢こう。

\section{摽識魚の系列を用いてかたよりのない凟源尾数を推定する方法}

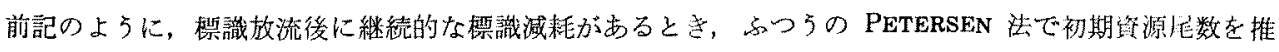

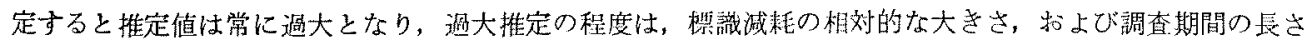

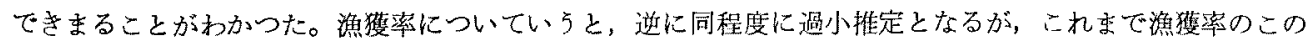
かたよりを除くのに再捕尾数の系列を用いる力法が考充られてきた ${ }^{1,2145 !}$ ここでは，これとやや畏なつた 標本標識掌の系列を用いて，このかたよりを除く方法について述べる。

放流後の第 $r$ 期の非標識魚の漁獲尾数 $C^{\prime} U$ ，を，

*この $Z$ の籁囲は以西底曳のグチ類，タイ類などの年生残率 ${ }^{61}$ から $Z$ を求め，これを月，旬などに区分 することを考えて選んだ。 


$$
C^{\prime}{ }^{\prime} \cdot=\frac{F U_{0}}{F+M} e^{-(F+M)(r-1)}\left(1-e^{-(F+M)}\right)
$$

で表わし，同期の標識魚の再捕昆数 $C^{\prime} x_{r}$ を，

$$
C_{X r}^{\prime}=\frac{F X_{0}}{F+M+T} e^{-(F+M+T)(r-1)}\left(1-e^{-(F+M+T)}\right)
$$

で表わすと，第 $\boldsymbol{r}$ 期の標本標㼁涼の逆数 $1 / p_{r}$ 注，

$$
\frac{1}{p_{r}}=1+\frac{U_{0}}{X_{0}} e^{(r-1) T} \frac{(F+M+T)\left(1-e^{-(F+M)}\right)}{(F+M)\left(1-e^{-(F+M+T)}\right)}
$$

から,

を得る。( $P$ は初めの標識婆)

$$
\frac{1}{p_{r}}-1=\left(\frac{1}{P}-1\right) \frac{(F+M+T)\left(1-e^{-(F+M)}\right)}{(F+M)\left(1-e^{-\left(F+M+T^{\prime}\right)}\right.} e^{(r-1) T}
$$

$P \ll 1$ のときは,

$$
\frac{1}{p_{r}}=\frac{1}{P} \frac{(F+M+T)\left(1-e^{-(F+M)}\right)}{(F+M)\left(1-e^{-(F+M+T)} e^{(r-1) T}\right.}
$$

あるい㤝，

$$
p_{r}=P \frac{(F+M)\left(1-e^{-(F+M+T)}\right)}{(F+M+T)\left(1-e^{-\left(F^{r}+M\right)}\right)} e^{-(r-1) T}
$$

となる。

(7)，(8) 式は $(r-1)$ に対して $\left(1 / p_{r}-1\right)$ ， あるい性 $1 / p_{r}$ の対数変換した值が，また (9) 式は $p_{r}$ の対 数变换した值が直線的に变化すること示している*。そして，これらの直線式の回帰倸数が植識減耗倸数 $T$ の推定值を与光, その $y$ 切片が初めの母標識率 $P$ についての情報をふくむこともかかる。

ここでは，単位期間の長さを短くとつて， $F, M, T$ などを小さく考孚ているので，(7)，(8) 式の右辺の分 数の部分は

の高次の項を無視して

$$
\frac{(F+M+T)\left(1-e^{-(F+M)}\right)}{(F+M)\left(1-e^{-(F+M+T)}\right)}=\frac{(F+M+T) \sum_{n=1}^{\infty}(-1)^{n-1} \frac{(F+M)^{n}}{n !}}{(F+M) \sum_{n=1}^{\infty}(-1)^{n-1}(F+M+T)^{n}}
$$

$$
\frac{(F+M+T)\left(1-e^{-(F+M)}\right)}{(F+M)\left(1-e^{-(F+M+T)}\right)} \sim 1+\frac{T}{2}
$$

と近似できる。したがつて，(7)，(8) 式を用いて得た面線式の $y$ 切片の值は $\log _{e}(1 / P-1)$ あるいは $\log _{e}$ (1/P) に活 $\log _{\rho}(1+T / 2)$ を加克たるのとなつている。よつて，これらのy切片の Antilog の招よそ $1 /(1+T / 2)$ 倍が $(1 / P-1)$ あるいは $1 / P$ の推定值となる。

$1 / P$ の推定ができれば, $\hat{N}_{0}=X_{0} / \hat{P}$ として, 初期資源眊数の推定ができる。さらに, $1 / P$ の分散も分散 の加成性 ${ }^{71,8), 9}$ 走用いて近似的に求められる。すな子ち，(7)，(8) 式を用いて得大值線式の $y$ 切片の值を $a$ とすると, $1 / P$ の分散は,

$$
V\left(\begin{array}{c}
\hat{1} \\
P
\end{array}\right)=\left(\frac{2 e^{a}}{2+T}\right)^{2}\left\{V(a)+\frac{V(T)}{(2+T)^{2}}-\frac{2}{2+T} V(a, T)\right\}
$$

で与充られる。 $V(a), V(T)$ は $a, T$ の分散, $V(a, T)$ はその共分散である。

したがつて, $1 / P$ の標集偏差は

$$
D\left(\frac{\hat{1}}{P}\right)=\left(\frac{2 e^{a}}{2+T}\right) \sqrt{V(a)+\frac{\overline{V(T)}}{(2+T)^{2}}-\frac{2}{2+T} V(a, T)}
$$

*あいつぐ $p_{r}$ が互いに独立でないことと，分散の一怺性に欠けるとい5点からいつて，この直線回帰の 訢算は便宜的なものである。 


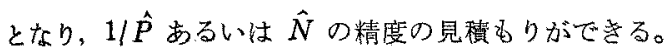

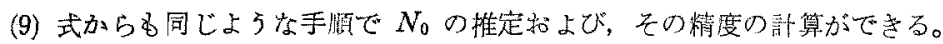

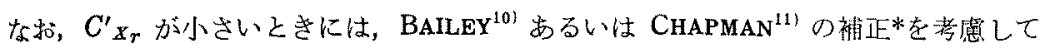

$$
\frac{1}{p_{r}}=\frac{C^{\prime} U_{r}+C_{X r}^{\prime}}{C^{\prime}{ }_{X r}+1}
$$

とするのが適当であるら。

以上は各期の漁獲努力量に変化のない場合であるが，洈獲努力舅が各期で変化するとき（さらに自然死亡 の大きさが変化しても) にも

$$
\frac{1}{p_{r}}-1=\left(\frac{1}{P}-1\right) \frac{\left((F+M)_{r}+T\right)\left(1-e^{-(F+M)} r\right)}{(F+M)_{r}\left(1-e^{-\left((F+M)_{r}+T\right)}\right)} e^{(r-1) T}
$$

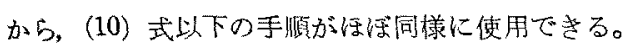

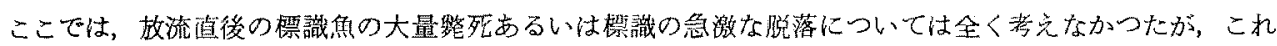

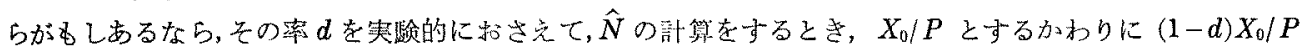
を用いればいい。

以上の方法では，標識減耗係数 $T$ が﨔独に推定できるので，再捕尾数の系列を用いて漁獾倸数と（自然

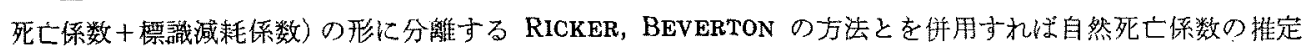
が可能となろう。これは，著者の力法で梆識率の該算 のさい, 標識減耗と無関倸の非標識魚の演獲尾数をも 用いているのでむしろ当然のことといえよう。

\section{モテル実験}

i) ビーズ実歌の手順と得られたデータ

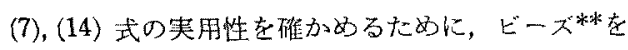
用いたモデル実䮖を行なつた。得られたデータについ て PETERSEN 式, BEVERTON 法による計算を死行な い,それそれれの結果を比較した。

㬰験の手順としては，まず直径 $26 \mathrm{~cm}$, 樑さ $10 \mathrm{~cm}$ の半球形のボウル(漁場)に白ビーズ (非標譏魚) 4000 , 赤ビーズ (栖識魚) 1000 , 計 5000 を入れて初期資源 尾数とした。これをよく拱接して，50，100，200の 四みをるつた构子を適宜使いわ外て，Table 2 の母数 に見合了必要数だけのサンプリングを行なつた。 $F$ ， $M$ あるいは $T$ が 0.01 とい5のは，それぞれ総数の 1/100 にあたる 50 個の標本をとることを意味する。 すなわら，京ず 100 個の標本をとり，半数の 50 を㴔 獾物，他の半数を自然死亡数とみなして，それぞれ白 玉，赤玉数を訢数後，全部を青玉に变觉てボウルにも

Table 2. The parameters given in each bead drawing experiment. $F$ : Fishing mortality coefficient, $T$ : Tag diminution coefficient. The other parameters are same in all experiment respetively, i. e., $M$, the natural mortality coeffcient $=0.01, N_{0}$, the initial size of population $=5000, P$, the initial tagged ratio $=0.20$.

\begin{tabular}{c|c|c|c}
\hline \multirow{2}{*}{ No. } & \multicolumn{2}{|c|}{ Parameters } & $\begin{array}{c}\text { Number of } \\
\text { Samples }\end{array}$ \\
\hline 1,2 & $F$ & $T$ & 0.01 \\
\hline 3,4 & 0.01 & 0.01 & 25 \\
\hline 5,6 & 0.01 & 0.04 & 25 \\
\hline 7,8 & 0.01 & 0.10 & 25 \\
\hline 9 & $\begin{array}{l}0.01^{*} \\
0.02\end{array}$ & 0.04 & 22 \\
\hline 10 & $\begin{array}{l}0.04 \\
0.01^{*} \\
0.02\end{array}$ & 0.04 & 25 \\
\hline
\end{tabular}

* One of them was randomly chosen at each drawing.

* BAILEY (1951) は再捕数が総捕獲数にくらべて小さいとき，PETERSEN 式の結果は，平均して正しい值 の $(1+1 / m)$ 倍 $(m$ は再捕期待数）になるとして（再捕数 +1$)$ を用いるといいとしている。CHAPMAN

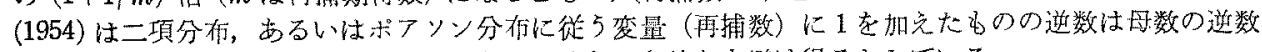
の不偏推定値であり，再捕数が 0 とい 5 面白くない条件を子避行得るとしている。

**白色のポリエチレン原料 (イーストマン裴) で直径約 $2 \mathrm{~mm}$ のほ活球状のもの，必要に応してその一

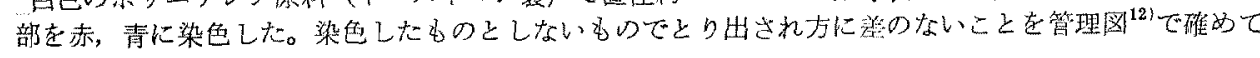
物恢。 
Table 3. Data obtained from the bead drawing experiment. (White: untagged fish. Red: tagged fish.)

(a) $F: 0.01, M: 0.01, T: 0.01$ (No. 1 and 2 in Table 2

No. \begin{tabular}{l|l|l}
\hline No. of Catch. & No. of Natural & $\begin{array}{c}\text { No. of } \\
\text { Diminu- } \\
\text { tion of } \\
\text { Tagged } \\
\text { fish. }\end{array}$ \\
\hline White Red Blue & White Red Blue & Red
\end{tabular}

(b) F: $0.01, M: 0.01, T: 0.02$ (No. 3 and 4 in Table 2)

\begin{tabular}{c|c} 
No. & No. of Natural \\
No. & $\begin{array}{c}\text { No. of } \\
\text { Diminu- } \\
\text { tion of } \\
\text { Tagged } \\
\text { fish. }\end{array}$
\end{tabular}

(c) F: $0.01, M: 0.01, T: 0.05$ (No. 5 and 6 in Table 2)

No. No. of Catch. $\quad \begin{gathered}\text { No. of Natural } \\ \text { Death. }\end{gathered} \begin{gathered}\text { No. of } \\ \text { Diminu- } \\ \text { tion of } \\ \text { Tagged } \\ \text { fish. }\end{gathered}$

\begin{tabular}{|c|c|c|c|c|c|c|c|c|c|c|c|c|c|c|c|c|c|c|c|c|c|c|c|}
\hline & & & & & & & & & & & & & & & & & & & & & & & \\
\hline $\begin{array}{l}1 \\
2 \\
3 \\
4 \\
5\end{array}$ & $\begin{array}{l}41 \\
40 \\
34 \\
38 \\
33\end{array}$ & $\begin{array}{r}9 \\
10 \\
14 \\
9 \\
12\end{array}$ & $\begin{array}{l}0 \\
0 \\
2 \\
3 \\
5\end{array}$ & $\begin{array}{l}41 \\
36 \\
39 \\
42 \\
39\end{array}$ & $\begin{array}{r}9 \\
14 \\
8 \\
6 \\
7\end{array}$ & $\begin{array}{l}0 \\
0 \\
3 \\
2 \\
4\end{array}$ & $\begin{array}{r}8 \\
8 \\
16 \\
3 \\
6\end{array}$ & $\begin{array}{l}1 \\
2 \\
3 \\
4 \\
5\end{array}$ & $\begin{array}{l}41 \\
37 \\
35 \\
37 \\
38\end{array}$ & $\begin{array}{r}9 \\
13 \\
13 \\
9 \\
8\end{array}$ & $\begin{array}{l}0 \\
0 \\
2 \\
4 \\
4\end{array}$ & $\begin{array}{l}37 \\
37 \\
44 \\
41 \\
46\end{array}$ & $\begin{array}{r}13 \\
9 \\
5 \\
7 \\
3\end{array}$ & $\begin{array}{l}0 \\
4 \\
1 \\
2 \\
1\end{array}$ & $\begin{array}{l}17 \\
16 \\
18 \\
20 \\
14\end{array}$ & $\begin{array}{l}1 \\
2 \\
3 \\
4 \\
5\end{array}$ & $\begin{array}{l}40 \\
41 \\
37 \\
32 \\
35\end{array}$ & $\begin{array}{r}10 \\
9 \\
10 \\
11 \\
10\end{array}$ & $\begin{array}{l}0 \\
0 \\
3 \\
7 \\
5\end{array}$ & $\begin{array}{l}38 \\
40 \\
36 \\
37 \\
43\end{array}$ & $\begin{array}{r}12 \\
10 \\
12 \\
10 \\
4\end{array}$ & $\begin{array}{l}0 \\
0 \\
2 \\
3 \\
3\end{array}$ & $\begin{array}{l}33 \\
32 \\
35 \\
29 \\
46\end{array}$ \\
\hline $\begin{array}{r}6 \\
7 \\
8 \\
9 \\
10\end{array}$ & $\begin{array}{l}36 \\
33 \\
39 \\
32 \\
37\end{array}$ & $\begin{array}{r}8 \\
7 \\
6 \\
11 \\
4\end{array}$ & $\begin{array}{r}6 \\
10 \\
5 \\
7 \\
9\end{array}$ & $\begin{array}{l}41 \\
36 \\
34 \\
37 \\
34\end{array}$ & $\begin{array}{r}4 \\
9 \\
11 \\
6 \\
8\end{array}$ & $\begin{array}{l}5 \\
5 \\
5 \\
7 \\
8\end{array}$ & $\begin{array}{r}7 \\
16 \\
10 \\
9 \\
8\end{array}$ & $\begin{array}{r}6 \\
7 \\
8 \\
9 \\
10\end{array}$ & $\begin{array}{l}40 \\
38 \\
27 \\
27 \\
39\end{array}$ & $\begin{array}{r}8 \\
8 \\
11 \\
17 \\
5\end{array}$ & $\begin{array}{r}2 \\
4 \\
12 \\
6 \\
6\end{array}$ & $\begin{array}{l}35 \\
34 \\
39 \\
37 \\
33\end{array}$ & $\begin{array}{r}9 \\
9 \\
5 \\
5 \\
10\end{array}$ & $\begin{array}{l}6 \\
7 \\
6 \\
8 \\
7\end{array}$ & $\begin{array}{r}14 \\
15 \\
14 \\
9 \\
12\end{array}$ & $\begin{array}{r}6 \\
7 \\
8 \\
9 \\
10\end{array}$ & $\begin{array}{l}33 \\
33 \\
35 \\
41 \\
32\end{array}$ & $\begin{array}{r}6 \\
9 \\
11 \\
4 \\
6\end{array}$ & \begin{tabular}{r|r|}
11 & 8 \\
4 & 5 \\
12 &
\end{tabular} & $\begin{array}{l}42 \\
38 \\
34 \\
30 \\
31\end{array}$ & $\begin{array}{r}5 \\
5 \\
10 \\
13 \\
7\end{array}$ & $\begin{array}{r}3 \\
7 \\
6 \\
7 \\
12\end{array}$ & $\begin{array}{l}40 \\
32 \\
33 \\
28 \\
33\end{array}$ \\
\hline $\begin{array}{l}11 \\
12 \\
13 \\
14 \\
15\end{array}$ & $\begin{array}{l}34 \\
30 \\
28 \\
36 \\
23\end{array}$ & $\begin{array}{r}4 \\
11 \\
6 \\
7 \\
9\end{array}$ & $\begin{array}{r}12 \\
9 \\
16 \\
7 \\
18\end{array}$ & $\begin{array}{l}37 \\
30 \\
31 \\
31 \\
25\end{array}$ & $\begin{array}{r}4 \\
10 \\
3 \\
3 \\
6\end{array}$ & $\begin{array}{r}9 \\
10 \\
16 \\
16 \\
19\end{array}$ & $\begin{array}{l}7 \\
5 \\
8 \\
8 \\
9\end{array}$ & $\begin{array}{l}11 \\
12 \\
13 \\
14 \\
15\end{array}$ & $\begin{array}{l}29 \\
25 \\
34 \\
35 \\
34\end{array}$ & $\begin{array}{r}11 \\
14 \\
7 \\
5 \\
2\end{array}$ & $\begin{array}{r}10 \\
11 \\
9 \\
10 \\
14\end{array}$ & $\begin{array}{l}37 \\
35 \\
37 \\
29 \\
27\end{array}$ & $\begin{array}{r}6 \\
5 \\
3 \\
7 \\
11\end{array}$ & $\begin{array}{r}7 \\
10 \\
10 \\
14 \\
12\end{array}$ & $\begin{array}{l}14 \\
12 \\
11 \\
14 \\
11\end{array}$ & $\begin{array}{l}11 \\
12 \\
13 \\
14 \\
15\end{array}$ & $\begin{array}{l}37 \\
37 \\
37 \\
37 \\
29\end{array}$ & $\begin{array}{l}2 \\
4 \\
3 \\
1 \\
7\end{array}$ & $\begin{array}{r}11 \\
9 \\
10 \\
12 \\
14\end{array}$ & $\begin{array}{l}33 \\
35 \\
30 \\
31 \\
30\end{array}$ & $\begin{array}{l}7 \\
6 \\
4 \\
5 \\
3\end{array}$ & $\begin{array}{r}10 \\
9 \\
16 \\
14 \\
17\end{array}$ & $\begin{array}{l}20 \\
19 \\
19 \\
22 \\
20\end{array}$ \\
\hline $\begin{array}{l}16 \\
17 \\
18 \\
19 \\
20\end{array}$ & $\begin{array}{l}29 \\
31 \\
25 \\
27 \\
22\end{array}$ & $\begin{array}{r}5 \\
4 \\
10 \\
7 \\
4\end{array}$ & $\begin{array}{l}16 \\
15 \\
15 \\
16 \\
24\end{array}$ & $\begin{array}{l}22 \\
30 \\
30 \\
30 \\
31\end{array}$ & $\begin{array}{r}10 \\
9 \\
4 \\
6 \\
7\end{array}$ & $\begin{array}{l}18 \\
11 \\
16 \\
14 \\
12\end{array}$ & $\begin{array}{l}7 \\
5 \\
5 \\
9 \\
2\end{array}$ & $\begin{array}{l}16 \\
17 \\
18 \\
19 \\
20\end{array}$ & $\begin{array}{l}30 \\
24 \\
27 \\
25 \\
26\end{array}$ & $\begin{array}{l}3 \\
7 \\
4 \\
8 \\
8\end{array}$ & $\begin{array}{l}17 \\
19 \\
19 \\
17 \\
16\end{array}$ & $\begin{array}{l}23 \\
29 \\
21 \\
31 \\
23\end{array}$ & $\begin{array}{l}5 \\
6 \\
7 \\
2 \\
9\end{array}$ & $\begin{array}{l}22 \\
15 \\
22 \\
17 \\
18\end{array}$ & $\begin{array}{r}12 \\
10 \\
5 \\
13 \\
10\end{array}$ & $\begin{array}{l}16 \\
17 \\
18 \\
19 \\
20\end{array}$ & $\begin{array}{l}30 \\
28 \\
30 \\
21 \\
28\end{array}$ & $\begin{array}{l}2 \\
3 \\
7 \\
6 \\
7\end{array}$ & $\begin{array}{l}18 \\
19 \\
13 \\
23 \\
15\end{array}$ & $\begin{array}{l}30 \\
32 \\
26 \\
26 \\
27\end{array}$ & $\begin{array}{l}0 \\
4 \\
3 \\
3 \\
5\end{array}$ & $\begin{array}{l}20 \\
14 \\
21 \\
21 \\
18\end{array}$ & $\begin{array}{l}16 \\
14 \\
16 \\
17 \\
12\end{array}$ \\
\hline $\begin{array}{l}21 \\
22 \\
23 \\
24 \\
25\end{array}$ & $\begin{array}{l}27 \\
24 \\
31 \\
25 \\
23\end{array}$ & $\begin{array}{r}8 \\
10 \\
5 \\
8 \\
9\end{array}$ & $\begin{array}{l}15 \\
16 \\
14 \\
17 \\
18\end{array}$ & $\begin{array}{l}20 \\
26 \\
28 \\
26 \\
21\end{array}$ & $\begin{array}{l}4 \\
6 \\
5 \\
4 \\
4\end{array}$ & $\begin{array}{l}26 \\
18 \\
17 \\
20 \\
25\end{array}$ & $\begin{array}{l}7 \\
3 \\
4 \\
6 \\
6\end{array}$ & $\begin{array}{l}21 \\
22 \\
23 \\
24 \\
25\end{array}$ & $\begin{array}{l}27 \\
28 \\
20 \\
27 \\
28\end{array}$ & $\begin{array}{l}3 \\
4 \\
3 \\
2 \\
2\end{array}$ & $\begin{array}{l}20 \\
18 \\
27 \\
21 \\
20\end{array}$ & $\begin{array}{l}29 \\
31 \\
25 \\
25 \\
22\end{array}$ & $\begin{array}{l}5 \\
1 \\
1 \\
1 \\
1\end{array}$ & $\begin{array}{l}16 \\
18 \\
24 \\
24 \\
27\end{array}$ & $\begin{array}{l}9 \\
6 \\
4 \\
4 \\
8\end{array}$ & $\begin{array}{l}21 \\
22 \\
23 \\
24 \\
25\end{array}$ & $\begin{array}{l}29 \\
29 \\
22 \\
30 \\
27\end{array}$ & $\begin{array}{l}3 \\
2 \\
4 \\
3 \\
2\end{array}$ & $\begin{array}{l}18 \\
19 \\
24 \\
17 \\
21\end{array}$ & $\begin{array}{l}28 \\
27 \\
28 \\
17 \\
29\end{array}$ & $\begin{array}{l}2 \\
3 \\
3 \\
5 \\
5\end{array}$ & $\begin{array}{l}20 \\
20 \\
19 \\
28 \\
26\end{array}$ & $\begin{array}{r}9 \\
9 \\
23 \\
17 \\
6\end{array}$ \\
\hline Sum. & 778 & 197 & 275 & 794 & 167 & 286 & 132 & Sum. & 778 & 184 & 288 & 807 & 145 & 298 & 292 & sum. & 810 & 142 & 298 & 806 & 145 & 299 & 580 \\
\hline
\end{tabular}

The figures in "No. of natural death" correspond to No. 2 experiment in Table 2.
The figures in "No. of natural death" correspond to No. 4 experiment in Table 2.
The figures in "No. of natural death" correspond to No. 6 experiment in Table 2 . 
(d) $F: 0.01, M: 0.01, T: 0.10$ (No. 7 and 8 in Table 2)

\begin{tabular}{|c|c|c|c|c|c|c|c|}
\hline \multirow[t]{2}{*}{ No. } & \multicolumn{3}{|c|}{ No. of Catch. } & \multicolumn{3}{|c|}{$\begin{array}{c}\text { No. of Natural } \\
\text { Death. }\end{array}$} & \multirow{2}{*}{$\begin{array}{l}\text { No. of } \\
\text { Diminu } \\
\text { tion of } \\
\text { Tagged } \\
\text { fish. } \\
\text { Red }\end{array}$} \\
\hline & White & Red & Blue & White & Red & Blue & \\
\hline 1 & 40 & 0 & 0 & 40 & 10 & 0 & 101 \\
\hline 2 & 41 & 9 & 0 & 40 & 9 & 1 & 99 \\
\hline 3 & 40 & 4 & 6 & 43 & 6 & 1 & 61 \\
\hline 4 & 36 & 6 & 8 & 32 & 12 & 6 & 72 \\
\hline 5 & 34 & 6 & 10 & 34 & 5 & 11 & 50 \\
\hline 6 & 36 & 4 & 10 & 35 & 8 & 7 & 51 \\
\hline 7 & 31 & 6 & 13 & 38 & 5 & 7 & 50 \\
\hline 8 & 36 & 2 & 12 & 36 & 5 & 9 & 46 \\
\hline 9 & 37 & 5 & 8 & 31 & 4 & 15 & 41 \\
\hline 10 & 27 & 4 & 19 & 36 & 2 & 12 & 21 \\
\hline 11 & 35 & 5 & 10 & 31 & 4 & 15 & 36 \\
\hline 12 & 30 & 4 & 16 & 31 & 2 & 17 & 24 \\
\hline 13 & 24 & 4 & 22 & 26 & 2 & 22 & 23 \\
\hline 14 & 32 & 2 & 16 & 37 & 2 & 11 & 21 \\
\hline 15 & 27 & 1 & 21 & 30 & $\overline{1}$ & 19 & 19 \\
\hline 16 & 26 & 1 & 23 & 31 & 2 & 17 & 16 \\
\hline 17 & 27 & 0 & 23 & 26 & 2 & 22 & 9 \\
\hline 18 & 28 & 0 & 22 & 26 & 1 & 23 & 13 \\
\hline 19 & 26 & 2 & 22 & 32 & 2 & 16 & 10 \\
\hline 20 & 22 & 0 & 28 & 26 & 1 & 23 & 6 \\
\hline Sum. & 635 & 75 & 290 & 661 & 85 & 254 & 769 \\
\hline
\end{tabular}

The figures in "No. of natural death" cor respond to No. 8 experiment in Table 2 . (e) $F$ was randomly chosen from one of $0.01,0.02$ and 0.04 at each drawing $M: 0.01, T: 0.04$ (No. 9 in Table 2)

\begin{tabular}{|c|c|c|c|c|c|c|c|}
\hline \multirow[t]{2}{*}{ No. } & \multicolumn{3}{|c|}{ No. of Catch. } & \multicolumn{3}{|c|}{$\begin{array}{c}\text { No. of Natural } \\
\text { Death. }\end{array}$} & \multirow{2}{*}{$\begin{array}{l}\text { No. of } \\
\text { Diminu } \\
\text { tion of } \\
\text { Tagged } \\
\text { fish. } \\
\text { Red }\end{array}$} \\
\hline & White & Red & Blue & White & Red & Blue & \\
\hline 1 & $\begin{array}{r}160 \\
39\end{array}$ & 40 & 0 & 37 & 11 & 2 & 40 \\
\hline
\end{tabular}

\begin{tabular}{l|l|l|l|l|l|l|l}
2 & 39 & 9 & 2 & 40 & 9 & 1 & 34 \\
3 & 40 & 6 & 4 & 40 & 7 & 3 & 35 \\
\hline
\end{tabular}

\begin{tabular}{r|r|r|r|r|r|r|r}
\hline 4 & 150 & 30 & 20 & 31 & 8 & 11 & 23 \\
\hline
\end{tabular}

\begin{tabular}{l|l|l|l|l}
5 & 71 & 10 & 19 & 37
\end{tabular}

\begin{tabular}{l|l|l|l|l|}
6 & 124 & 30 & 46 & 24 \\
\hline
\end{tabular}

\begin{tabular}{r|r|r|r|r|r|r|r|r|}
7 & 62 & 12 & 26 & 39 & 12 & 14 & 23 \\
\hline
\end{tabular}

\begin{tabular}{r|r|r|r|r|r|r|r|}
8 & 124 & 30 & 46 & 31 & 3 & 16 & 21 \\
9 & 117 & 20 & 63 & 23 & 7 & 20 & 21
\end{tabular}

\begin{tabular}{|r|r|r|r|r|r|r|r}
9 & 117 & 20 & 63 & 23 & 7 & 20 & 21 \\
10 & 109 & 9 & 82 & 26 & 5 & 19 & 21
\end{tabular}

\begin{tabular}{l|l|l|l|l|l|l|l}
11 & 103 & 22 & 75 & 26 & 4 & 20 & 14 \\
\hline
\end{tabular}

\begin{tabular}{r|r|r|r|r|r|r|r|}
12 & 114 & 14 & 72 & 30 & 4 & 20 & 14 \\
12 & 14 & 3 & 26 & 26 & 5 & 19 & 20 \\
\hline
\end{tabular}

\begin{tabular}{l|r|r|r|r|r|r|l}
13 & 21 & 3 & 26 & 26 & 5 & 19 & 10 \\
14 & 20 & 6 & 24 & 23 & 4 & 23 & 10 \\
15 & 26 & 3 & 21 & 23 & 2 & 25 & 13
\end{tabular}

\begin{tabular}{r|r|r|r|r|r|r|r}
16 & 81 & 17 & 102 & 23 & 2 & 25 & 18 \\
17 & 83 & 15 & 102 & 18 & 4 & 28 & 9
\end{tabular}

\begin{tabular}{l|l|l|l|l|l|l|}
17 & 83 & 15 & 102 & 18 & 4 & 28 \\
18 & 68 & 13 & 119 & 18 & 2 & 30
\end{tabular}

\begin{tabular}{r|r|r|r|r|r|r|}
18 & 68 & 13 & 119 & 18 & 2 & 30 \\
19 & 21 & 0 & 29 & 12 & 1 & 39 \\
\hline
\end{tabular}

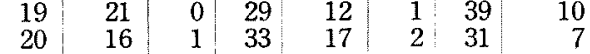

\begin{tabular}{l|l|l|l|l|l|l|l|}
21 & 67 & 14 & 119 & 18 & 0 & 32 & 9 \\
22 & 69 & 11 & 120 & 12 & 1 & 37 & 3
\end{tabular}

$\begin{array}{llllllll}\text { Sum. } & 1685 & 315 & 1060 & 574 & 99 & 427 & 410\end{array}$ (f) $F$ was randomly chosen from one of $0.01,0.02$ and 0.04 at each drawing. $M: 0.01, T: 0.04$ (No. 10 in Table 2)

\begin{tabular}{|l|c|c|c|} 
No. & No. of Catch. & No. of Natural & $\begin{array}{l}\text { No. of } \\
\text { Diminu- } \\
\text { tion of } \\
\text { Tagged } \\
\text { fish. }\end{array}$ \\
\hline
\end{tabular}

White Red Blue White Red Blue Red

\begin{tabular}{r|r|r|r|r|r|r|r}
\hline 1 & 154 & 46 & 0 & 41 & 7 & 2 & 36 \\
2 & 36 & 13 & 1 & 39 & 9 & 2 & 37 \\
3 & 40 & 8 & 2 & 37 & 9 & 4 & 42 \\
4 & 38 & 8 & 4 & 36 & 11 & 3 & 35 \\
5 & 70 & 19 & 11 & 35 & 7 & 8 & 31 \\
& & & & & & & \\
6 & 37 & 6 & 7 & 35 & 9 & 6 & 25 \\
7 & 139 & 30 & 31 & 36 & 5 & 9 & 28 \\
8 & 33 & 5 & 12 & 32 & 3 & 15 & 24 \\
9 & 134 & 16 & 50 & 30 & 10 & 10 & 18 \\
10 & 55 & 18 & 27 & 31 & 7 & 12 & 14 \\
& & & & & & & \\
11 & 35 & 3 & 12 & 23 & 10 & 17 & 17 \\
12 & 51 & 9 & 40 & 29 & 9 & 12 & 20 \\
13 & 60 & 12 & 28 & 23 & 4 & 23 & 18 \\
14 & 22 & 4 & 24 & 27 & 3 & 20 & 15 \\
15 & 30 & 2 & 18 & 25 & 7 & 18 & 15 \\
& & & & & & & \\
16 & 27 & 1 & 22 & 25 & 4 & 21 & 16 \\
17 & 50 & 2 & 48 & 28 & 8 & 14 & 12 \\
18 & 47 & 7 & 46 & 30 & 3 & 17 & 8 \\
19 & 21 & 2 & 27 & 26 & 1 & 23 & 9 \\
20 & 24 & 2 & 24 & 22 & 2 & 26 & 12 \\
& & & & & & & \\
21 & 44 & 7 & 49 & 29 & 4 & 17 & 7 \\
22 & 34 & 4 & 62 & 19 & 3 & 28 & 9 \\
23 & 81 & 12 & 107 & 23 & 2 & 25 & 7 \\
24 & 81 & 8 & 111 & 15 & 2 & 33 & 8 \\
25 & 43 & 6 & 51 & 26 & 3 & 21 & 8 \\
\hline Sum. & 1386 & 250 & 804 & 722 & 142 & 415 & 471 \\
\hline & & & & & & \\
\hline
\end{tabular}




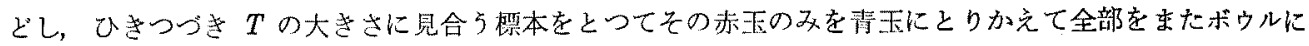
もどした。これが第 1 同のサンブリングである。第 2 回目以後も同倳の手顺にしたがつて演獾物，自然死亡

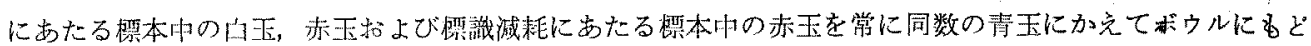
した。したがつて，ボウルのなかの白玉，赤玉注徐々に滅り，青玉は增光るが総数は常に 5000 である。い

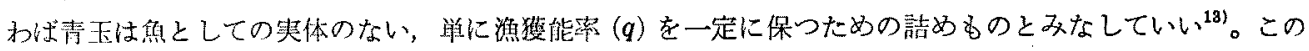
上うなサンプリングを Table 2 の右端に示した回数だ讨継綂して行ない, Table 3 に示すようなデータを

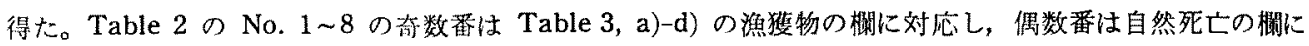
当たる。これは， $F, M$ がともに 0.01 で开いに他と双なし得ることによる。Table 2 の No. 9 と No. 10

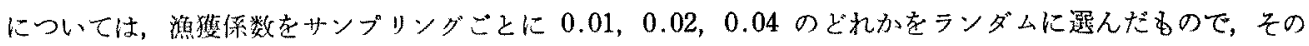
データは Table 3 の) と f) である。これは漁獲保数が各期で变わる(14) 式を用いるためのるのであ る。

な拉，ここでは便穴上，標識娍耗はすべて標識魚の死亡の形で起こるるのとし，標識の脱落した標識魚が

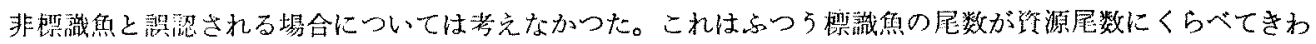
めて小さく、したがつてその影概もこく小さいことを考虑したからである。

ii) 部算結果と艺の比較检隔

Table 3 のデータを用いて, ふつ5の PETERSEN 式, 落者の (7), (14) 式, 就よ゙ BEVERTON の方法で

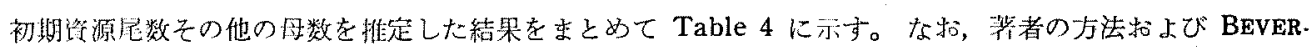
TONの方法を用いるさい，再捕尼数0の標本は除外して計算を進めたことを付記して括く。

Table 4. Comparison of estimates among three methods.

$\hat{N}$ : the estimate of initial size of population.

$\hat{N}_{L}, \hat{N}_{U}$ : the lower and upper limits of $95 \%$ confidence interval.

\begin{tabular}{|c|c|c|c|c|c|c|c|c|c|c|c|}
\hline \multirow[b]{2}{*}{ No. } & \multicolumn{3}{|c|}{ Petersen Method } & \multicolumn{3}{|c|}{ Author's Method } & \multicolumn{4}{|c|}{ Beverton Method } & \multirow[b]{2}{*}{$\hat{M}^{3)}$} \\
\hline & $\hat{N}$ & $\hat{N}_{L}-\hat{N}_{U}{ }^{11}$ & $r=\frac{\hat{N}}{N_{0}}$ & $\hat{N}$ & $\hat{N}_{L}-\hat{N}_{U}$ & $\hat{T}$ & $\hat{F}$ & $(\hat{M}+\hat{T})$ & $\hat{N}$ & $\hat{N}_{L}-\hat{N}_{U}$ & \\
\hline 1 & 4949 & 5671 & 0.990 & 5434 & $3966-$ & 0 & 8886 & & 5643 & 3564 & 0.00619 \\
\hline 2 & 772 & $5060-6718$ & .154 & 5938 & 4283 & 0.00246 & 0.00843 & 0.01800 & 5930 & 457 & 554 \\
\hline 3 & 5228 & $4616-6027$ & 1.046 & 3907 & 2664 & 0.04460 & 0. & 61 & 3792 & 275 & 0.00701 \\
\hline 4 & 6566 & $5695-7752$ & 1.313 & 4973 & 278 & 0.04591 & 0.01066 & 0.0 & 4670 & 278 & 0.01390 \\
\hline 5 & 6704 & $5805-7932$ & 1.541 & 5112 & $3445-6779$ & 0.03518 & 0.00916 & 0.04660 & 5459 & 383 & 0.01142 \\
\hline 6 & 6559 & $5689-7744$ & 1.312 & 5198 & 3685 & 0.03097 & 0.00969 & 0.0 & 5159 & 396 & 0.01122 \\
\hline 7 & 9467 & $7770-12112$ & 1.893 & 5863 & 3856 & 0.07337 & 0.00830 & 0.09215 & 6027 & $4340-10058$ & 0.01878 \\
\hline 8 & 8776 & $7288-11028$ & 1.753 & 4909 & $3966-5852$ & 0.10081 & 0.01010 & 0.11070 & 4949 & $3856-6909$ & 0.00989 \\
\hline 9 & 6356 & $5760-7089$ & 1.271 & 5399 & $3756-7042$ & $0.03583^{q}$ & & 0.04028 & 5222 & - & 0.00455 \\
\hline 10 & 6544 & $5820-7485$ & 1.309 & 5095 & $3506-6684$ & 0.04473 & 0.00 & - & - & - & - \\
\hline
\end{tabular}

1) Obtained from the Normal-Binomial distribution.

2) $q$ : catchability coefficient.

3) $\hat{M}$ is obtained from $(M+T)$ in the BEverTon method and $T$ in the Author's method.

Table 4 で明らかなように, ふつうの PETERSEN 式による推定値 $\hat{N}$ は標識减耗媇数の增加にともなつ

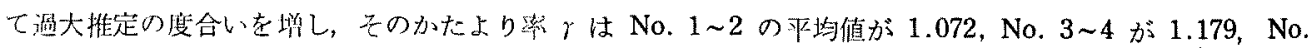
$5 \sim 6$ が 1.326, No. 7 8 で 1.823 となつている。No. 5 6 と No. 9 10 とる $T$ は 0.04 であるが, No. 9 10のF の活 万が No. 5 6 の場合上り大きかつたので，活んの少しではあるが，かたより率は No. 9 10 の場合に小さくなつている。米た，ここで与えた条件のもとでは，Tが 0.04 以上になると $\hat{N}$ の信頼限界はもは中真の值 5000 在はさんでいない。 
(7)，(14）式を用いて計算した結果は，No. 1，2 を除いて回㷌湎はすでて統計的に有意であつた。 $1 / p_{r} の$ バラッキはかなり大きいから Tが小さいときには有意となりにくいのであるう。 $X_{0} / \hat{P}$ として得た $\hat{N} は T$ が大きい場合でもその影響は除かれてまず妥当なるのとなつている。ただし，信頼限界の巾は少し広くなる ので，Tが0に近くて回帰が有意となら婸合はPETERSEN 式そのものを用いるのが有利であるとい兄る。 これは，単に $\left(1 / p_{r}-1\right)$ の時間に対する散布図を画くことによつても拉よその見当がつけられるだろろ。標 識减耗保数 $T$ の推定值はときに当たり，ときに多少のズレを示している。

BEVERTON の方法による結果は，No. 1，9，10 を除いて回帰が有意となつた。 $F,(M+T)$ の推定值車妥

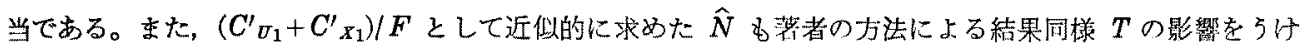
ないが，信頼限界の巾はかなり広くなる上らである。

ここで，注意して拓きたいのは，漁獲努力量が各期で変わる場合，すなわち No. 9, 10 の回㷌が有意とな らなかつたことである。わずか 2 例なのでもちろんはつきりしたことはい充ないが，ランダマイズしやすい ビーズ央験でこの結果を示したことは，反覆計算を必要とする BEVERTON の方法を夷際のデータに適用す るときの网難さを暗示しているょうに思われる。この点をさらに確かめるため, No. 9 (Table 3-e)) につ

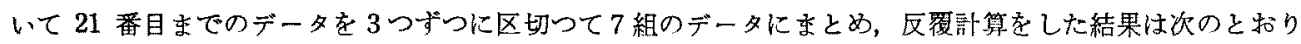
であつた。

$\left(q_{1}=0.0062,(M+T)_{1}=0.170\right), \quad\left(q_{2}=0.0123, \quad(M+T)_{2}=0.116\right), \quad\left(q_{3}=0.0164, \quad(M+T)_{3}=0.0789\right), \quad\left(q_{4}=\right.$ 0.0193， $\left.(M+T)_{4}=0.0533\right),\left(q_{5}=0.0166,(M+T)_{5}=0.0776\right)_{0}$ 第 1 期間の演獲努力骨は $4+1+1=6$ であ り，この期間の総漁獲尾数忙 $200+48+46=294$ であるかから，初期凟源尾数を近似的に求めると，

$$
\hat{N}=\frac{294}{6 \times 0.0166}=2940
$$

となりかなりの過小推定になる。同じデータについて PETERSEN 式で計算すると $\hat{N}=6316$, 著者の方法 では $\hat{N}=5189$ を得る。また，Tの推定傎として 0.0306 を得た。(日数は 0.04)

同槏に， No. 10 (Table 3-f))についても 24 番目までのデータを3つづつ 8 組にして BEVERTON 法で 計算すると， $q_{1}<0$ となり推定不能であつた。このときの PETERSEN 式の結果は $\hat{N}=6504$ ，著者の力法 では $\hat{N}=4501$ であつた。また， $T=0.0462$ を得た。このよ5に，データを組みかえた結果も，㴔獲努力量 が各期で変わるときの BEVERTON の反覆計算法はいい結果を与光なかつたことを記して打く。

さて，著者の方法で得た $T$ と，BEVERTON 法で得た $(M+T)$ とから，自然死亡倸数 $M$ を推定した結 果は, Table 4 の右端に示したと和りであつて，この2つの方法の例用によつてごく和括ざつばにではある が，Mの推定が可能であることがわかる。

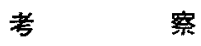

以上の結果から見て，標識放流後に継続して標識減耗があるをき，ふつうの PETERSEN 法を用いた場合 に生しる推定值のかたよりは罱者の力法でほほ除き得るものと思われた。同じモデル实駼のデータに可捕尼

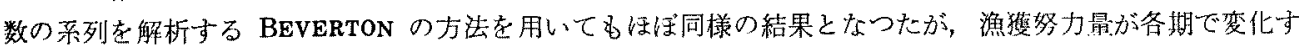
る場合についてはいい結果が得られなかつた。漁獲努力聂が各期で変化する場合の BEVERTON 法はかなり

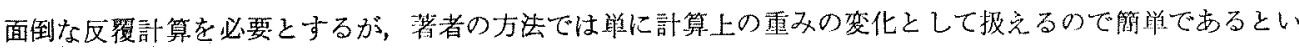
える。しかし，その反面，標本標識率の系列を用いるときには，放流後に加入 (Recruitment) があると，

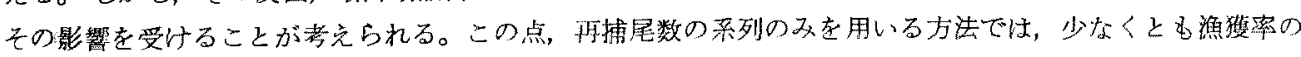
推定のさいには加入群の存在を無視し得るので有利であるとい兄る。

また，標識率法では初期覚源尾数の推定のさい，常に有效標識尾数が必要である。したがつて，対象とす る魚種の強弱, あるいは用いる標識法の種類によつて, 放流㨁後に標識魚の大量整死あるいは標識の急激な 脱落があるときには，標識魚の一時的な蓄厎によつてこれらが終るのを待つてから放流するか，むるいは寒 


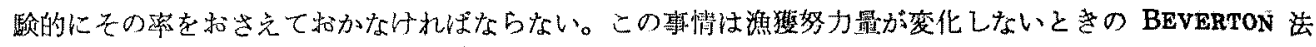
に特いてす同棣である。潐獲努力量が各期で变化するときの BEVERTON の反覆計算法は放流尾数をその式 中に含まないので，この型の隇耗の有無にかかわらず，漁萑能率 $q$ をかたよりなく推定できるとされている

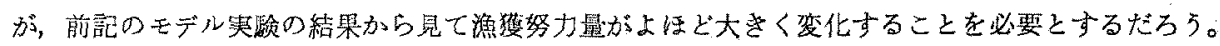

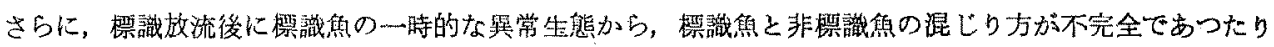

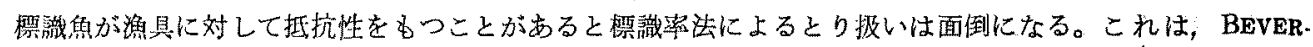
TON 法でも同様であつて，一般にこの䅜の原因による推定值のかたよりはとり除くことが困難である。

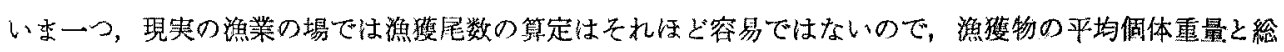
潐猚最から漁獾尾数を推定する必裂も生じう。

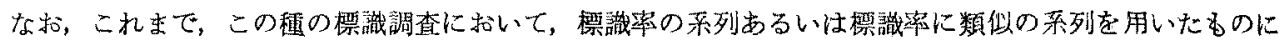

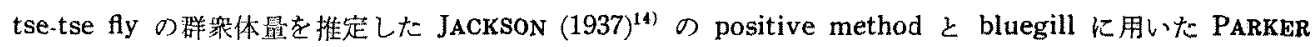
$(1955)^{151}$ の磦識率の逆正弦恋换法がある。いずれる，加入の影響を除いてかたよりのない初期個体数を推定 しょ5とい5もので，それぞれに照昧深い。

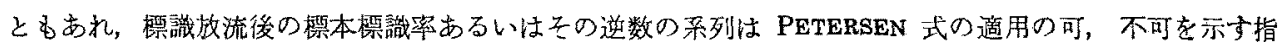
蝶であつて，これらの系列が傾向的な変化在示さないときには，推定值の精度の点からいつても，計算の容 易さからいつても PETERSEN 式そのものの適用が望变しいとい方。多少，形仕罢なるが OLSON (1957) が walleye の瓷源尾数を推定するさい，绛力当たり丽捕尾数の系列と努力当たり㴔獾尾数の系列とを対比

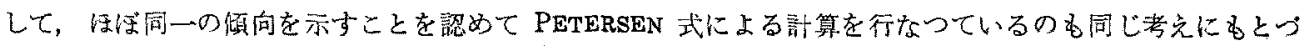
くあといをる。

この栖譩率法による实祭のフィールドのデータの解析結果, あるいは加入のあるときの標識率法について はひきつづき別報で㣮告する卢定でする。

\section{要䄪}

1. 栖識放流後に継続的な絮識減耗があるとき，ふつ50 PETERSEN 式を用いて得られる初期資源尾数 の推定傎は常に過大であり，過大推定の程度は調查期間が長くなるにしたがつて增大し，全減少係数之標譏 减耗倸数の大きざきるかたより绿の最大值 $(Z+T) / Z$ に近づく傾向をるつ。

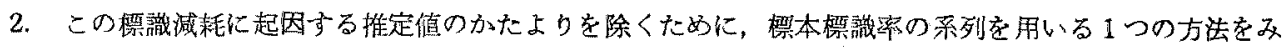
らびいた。この方法と，従来の再捕尾数の系列を解析する方法とを任用すれば自然死亡係数の推定す可能で ある。

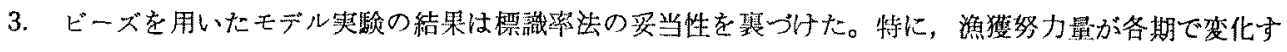
る湶合に有效であることがわかつた。また，同じビーズ実験のデータに PETERSEN 法，BEVERTON 法を用 いた結果と比蔽して，その得失を諭じた。

\section{文献}

1) RICKER, W. E.: Methods of estimating vital statistics of fish populations. Indiana Univ. Publ., Sei. Ser., No. 15, 101 pp. (1948).

2) _- Hand-book of computations for biological statistics of fish populations. Fish. Res. Bd. Canada, Bull., 119, 300 pp. (1958).

3) ClARK, F.N. and JANSSEN, J.F.: Results of tagging experiments in California waters on the sardine (Sardinops caerulea). Calif. Div. Fish and Game, Fish Bull., No. 61, 1 42 (1945).

4) Beverton, R.J.H.: Notes on the use of theoretical models in the study of the dynamics of exploited fish populations. U.S. Fish Lab., Beaufort, N.C., Misc. Contr., No. 2, 159 py.

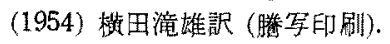

5) —-, and HoLT S. J.: On the dynamics of exploited fish populations. Fish. Invest., 
Ser. II, XIX, 533 pp. (1957).

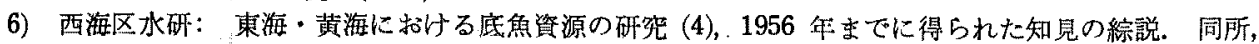
114 pp. (1957).

7) DEMING, W.E.：推計学によるデータのまとめ方．森口繁一訳，岩波畫店，東京，27３2 (1950).

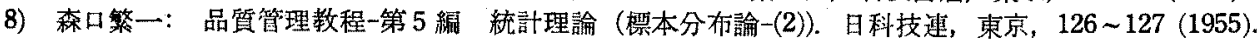

9）能勢㚔雄：DELURY の資源量推定法の推定值に対する信頼区間について．本誌，24 (12)，953 956 (1959).

10) BalleY, N.J. J.: On estimating the size of mobile populations from recapture data. Biometrika, 38, 293 306 (1951).

11) Chapman, D. G.: The estimation of biological populations. Ann. Math. Statistics, 25, 1 15 (1954).

12）日科技速：管理図法，同速盟，東京，731 pp. (1955).

13) DeLuRY, D.B.: On the planning of experiments for the estimation of fish populations. J. Fish. Res. Bd. Canada, 8, 281 307 (1951).

14) JACKson, C.H.N.: Some new methods in the study of Glossina moristans. Proc. Zool. Soc. London, 4, $811 \sim 896$ (1937).

15) PARKer, R.A.: A method for removing the effect of recruitment on PETERSEN-type population estimate. J. Fish. Res. Bd. Canada, 12, $447 \sim 450$ (1955).

16) Olson, D. E.: Statistics of a walleye sport fishing in a Minnesota lake. Trans Amer. Fish. Soc., 87, 52 72 (1957). 